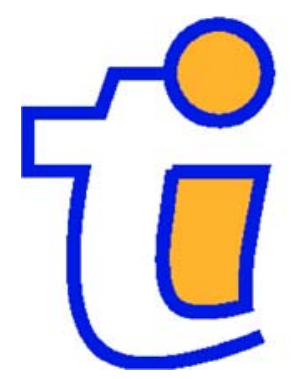

TI 2005-072/2

Tinbergen Institute Discussion Paper

Preferential Trade Arrangements and the Pattern of Production and Trade when Inputs are Differentiated

Joseph Francois 


\section{Tinbergen Institute}

The Tinbergen Institute is the institute for economic research of the Erasmus Universiteit Rotterdam, Universiteit van Amsterdam, and Vrije Universiteit Amsterdam.

Tinbergen Institute Amsterdam

Roetersstraat 31

1018 WB Amsterdam

The Netherlands

Tel.: $\quad+31(0) 205513500$

Fax: $\quad+31(0) 205513555$

Tinbergen Institute Rotterdam

Burg. Oudlaan 50

3062 PA Rotterdam

The Netherlands

Tel.: $\quad+31(0) 104088900$

Fax: $\quad+31(0) 104089031$

Please send questions and/or remarks of nonscientific nature to driessen@tinbergen.nl.

Most TI discussion papers can be downloaded at http://www.tinbergen.nl. 


\title{
Preferential Trade Arrangements and the Pattern of Production and Trade when Inputs are Differentiated ${ }^{\dagger}$
}

\author{
Joseph Francois \\ Tinbergen Institute and CEPR
}

July 2005

\begin{abstract}
This paper is concerned with rules of origin when intermediate goods are differentiated. An analytical model emphasizes trade patterns and the relative importance of trade in intermediates given trade preferences. Econometric evidence based on intra-OECD trade in motor vehicles and motor vehicle parts points to a systematic impact of trade costs and FTA membership, following from rules of origin and reduction in border measures, on the role of intermediates and their relative importance in production and trade. These results are consistent with a conceptual framework involving rules-base trade costs and two-way trade in differentiated intermediate goods and final goods.
\end{abstract}

Keywords: rules of origin, trading costs, trade in intermediates, industry location JEL codes: F15, F13

† Special thanks are due to Michael Ferrantino, Kala Krishna and Olivier Cadot for constructive comments on an earlier draft. Address correspondence to:

J.Francois, Tinbergen Institute (Rotterdam), Erasmus University Rotterdam, Burg Oudlaan 50-H8-18, 3000DR Rotterdam, Netherlands. Email: francois@,few.eur.nl

Fax: +31 104089146 . 


\title{
Preferential Trade Arrangements and the Pattern of Production and Trade when Inputs are Differentiated
}

\begin{abstract}
This paper is concerned with rules of origin when intermediate goods are differentiated. An analytical model emphasizes trade patterns and the relative importance of trade in intermediates given trade preferences. Econometric evidence based on intra-OECD trade in motor vehicles and motor vehicle parts points to a systematic impact of trade costs and FTA membership, following from rules of origin and reduction in border measures, on the role of intermediates and their relative importance in production and trade. These results are consistent with a conceptual framework involving rules-base trade costs and two-way trade in differentiated intermediate goods and final goods.
\end{abstract}

Keywords: rules of origin, trading costs, trade in intermediates, industry location JEL codes: F15, F13

\section{Introduction}

Rules of origin are an important aspect of preferential trade agreements (PTAs). They affect both North-South free trade agreements (FTAs), like U.S.-Mexico trade under the NAFTA, and North-North trade, like U.S.-Canada trade and EU trade with other European economies under various FTAs. They have also been blamed for the failure of developing country trade preference schemes. Baldwin (2001) warns of their potential use as technical barriers to trade.

The relevance of rules of origin in recent preferential trade schemes has spawned a new formal literature. This includes exploration of the importance of rules of origin for the political economy of regional agreements (Duttagupta and Panagariya 2001), as well as the impact of rules of origin on outside country access to internal markets (Ju and Krishna 1998). Other work of this type includes Falvey and Reed (1998) and Krishna and Krueger (1995).

The roots of rules of origin regimes can be found in the relative complexity of PTAs vis-à-vis customs unions. For example, because free trade agreements (FTAs) do not have a common external tariff, the risk exists that goods will be diverted through the lowest FTA-partner tariff and into the FTA block. Because of this possibility, one stated reason for rules of origin is that they are designed to ensure that only goods produced 
within a free trade block actually receive free trade treatment. At least, that is the theory. ${ }^{1}$ In practice, assigning the origin of a product is not simple, as value added is sometimes included and sometimes not, local content thresholds vary, and products can and do lose their FTA origin as they cross borders. In addition, the assignment of origin is clearly subject to political factors, much like contingent protection.

In Europe, a regime of "Pan-European cumulation," entered into force on 1 January 1997. It originally applied in all of the EEA countries (Norway, Iceland, Liechtenstein, Sweden, Finland, Denmark, the UK, Ireland, Germany, Luxembourg, the Netherlands, Belgium, France, Austria, Italy, Spain, Portugal and Greece), in Switzerland (EFTA member), and in Estonia, Latvia, Lithuania, Poland, the Czech Republic, Slovakia, Hungary, Bulgaria, Romania and Slovenia. Turkey joined in late $1999{ }^{2}$ and is working to implement the regime. The European rules require that the inputs in fact originate within the free trade area. Otherwise, processing requirements in the rules of origin have to be complied with if the finished product is to have free trade status. A similar arrangement for the Mediterranean countries is due to take effect by 2010 .

In the North American Free Trade Agreement (NAFTA), the rules of origin state that a product originates in the free trade area when it is wholly produced or substantially transformed in the free trade area. Substantial transformation occurs when processing causes a product to shift from one tariff classification to another. NAFTA rules of origin include a "de minimis" provision that permits a final NAFTA good to contain a small quantity of the same kind of good from a non-NAFTA source (up to 7 percent of the value of each shipment, or 9 percent in the case of cigarettes and cigars). The motor vehicle sector was heavily involved in the design of the NAFTA rules of origin, and from the beginning it was clear that their purpose was to provide additional protect to intermediate parts producers and to increase costs for integrated operations owned by Japanese automakers.

Much of the literature on rules of origin works from the premise of homogenous goods. This is in keeping with a large part of the literature on trade creation and diversion under PTAs. In contrast, this paper is concerned with rules of origin in the context of Ethier-type two-way trade in differentiated intermediate goods (Ethier 1979,

\footnotetext{
${ }^{1}$ See Bhagwati and Panagariya (1996) and Panagariya (2000) for more on this point.

2 Turkey originally signed protocols for accession to the system of European cumulation in late 1999, though by 2001 (relevant for the empirics in Sections 3 and 4) transitional arrangements were still being implemented. The most critical effect has been to strengthen the operational effectiveness of the customs union between the EU and Turkey.
} 
1982). Such differentiation of intermediates is an important aspect of recent division of labor models of trade, geography, and growth (Francois and Nelson 2002). The analytical approach followed here is similar in spirit to that taken in ex ante studies of the impact of the NAFTA on the automobile industry. ${ }^{3}$ Manufacturing involves use of intermediate inputs that are differentiated by intermediate firms, with two-way trade of intermediates and benefits from an increased division of labor through trade. Emphasis is placed on the pattern of production and trade in such a framework, and in particular on the relative importance of trade in intermediates vis-à-vis trade in final goods when rules or origin are imposed on a trade-equilibrium.

While the literature stresses the discriminatory impact of PTAs with rules of origin, there is at the same time an inherent ambiguity regarding rules of origin, at least when we make comparisons to customs union regimes. This is because regional agreements can reduce internal trading costs. In particular, while FTAs punish use of external intermediates, customs unions (CUs) and ancillary trade facilitation measures may reward the use of internal intermediates, reducing the costs of moving goods crossborder. ${ }^{4}$ These carrot and stick mechanisms both work in the same direction, which means that the impact of use of rules of origin in FTAs on trade in intermediates vis-àvis similar trade in a customs union without need of rules of original is actually ambiguous. We highlight this issue here, stressing the theoretical impact of rules of origin, while isolating these from border effects (realized through cost reductions in customs unions) in the empirics.

The paper is organized as follows. An analytical model is first developed in Section 2, from which basic expectations are developed regarding differences between rules of origin (i.e. FTAs instead of customs unions) and the pattern of trade and production in intermediate and final goods. A technical innovation here involves the conceptual use of an actual set of global equilibrium prices for the examination of trade between different pairs of countries under various rules of origin. The theory-based discussion is followed by a formal econometric cross-section analysis of OECD bilateral trade in finished motor vehicles and parts. The econometric evidence suggests that FTA rules of origin can be an effective barrier against third-country suppliers of intermediate goods. In the context of Europe, trade facilitation measures (the European carrot rather

\footnotetext{
${ }^{3}$ See Lopez-de-Silanes, Markusen, and Rutherford (1994).

${ }^{4}$ In both the $200+$ year old North American customs union (i.e. the United States), and in the European Union since the single-market was implemented in the early 1990s, goods move more or less freely across internal borders.
} 
than the NAFTA stick) dominate, revealing the importance of border effect mitigation within customs unions. In addition, while European accumulation rules are discriminatory against third countries, they appear to extend most of the benefits of customs union membership (apart from border effects) to the larger European Economic Area.

\section{Analytical Expectations}

In this section the impact of PTAs on intermediates trade is explored in an analytical framework involving Ethier-type two-way trade in differentiated intermediates (Ethier 1979, 1982). ${ }^{5}$ Domestic and imported intermediate goods are specialized compliments in production, and potential gains from the division of labor in intermediate goods, and with intermediate goods themselves being used to produce final, traded goods. In formal terms, we examine the properties of PTA partners within a global trading equilibrium. This allows us to take world prices as given at actual equilibrium values as we examine a given set of countries, and to then focus on differences across PTA country pairs within the equilibrium price set as implied by differences in rules of origin. We are able to then isolate expected intra-PTA differences related directly to rules-based costs for use of non-PTA intermediates.

We focus on three countries, indexes by $i=1 \ldots 3$. Countries 1 and 2, on impose an PTA that leaves out country 3. Country 3 represents the rest-of-world region vis-à-vis countries 1 and 2, and is represented in the system by world prices representing the trade equilibrium price set. For both countries 1 and 2, we assume a transformation technology $g($.$) that maps production of the numeraire good wheat, represented by W$, and intermediate factor bundles, represented by $b$, used in the production of manufactured goods, both as inputs to intermediate input production and as value added.

Formally, our transformation technology is represented by equation (1). It has the usual properties of convexity.

$$
b^{i}=g^{i}\left(W^{i}\right), \quad i=1,2 \quad g^{\prime}, g^{\prime \prime}<0
$$

Assuming $W$ is homogenous, we set the intra-PTA price of wheat at unity, and give it the job of serving as numeraire. We can then represent the supply price of bundles

\footnotetext{
${ }^{5}$ The analytical model developed here is similar in spirit to Lopez-de-Silanes, Markusen Rutherford (1994), Markusen, Rutherford, and Hunter (1995) and Francois (1994).
} 
(assuming competitive factor markets) as an artifact of the transformation technology. These are formalized in equations (2) and (3). ${ }^{6}$

$$
p_{b}^{i}=-\left(\left(g^{i}\right)^{\prime}\right)^{-1}
$$

$$
P_{W}^{i}=1 \quad i=1,2
$$

We next turn to intermediate goods. We are interested in two-way trade in intermediates. In reduced form, we will have a mapping from bundles prices to prices for composite intermediates. This is represented in equation (4). The $h$-function in equation (4) is a consequence of increasing returns to specialization in intermediate goods, and from the primal functional mapping of bundles to intermediates (Francois and Nelson 2002). It builds on the following property of Ethier-type trade models with a CES-aggregator for traded intermediates. With some manipulation we can represent the reduced form system as one involving a composite region specific intermediate good $m$ produced under external increasing returns to scale. In terms of the region-indexed intermediate good, the remainder of the intermediate demand system can then be modeled as one involving CES-type preferences with regional rather than firm indexing. ${ }^{7}$

$$
P_{m}^{i}=h\left(m^{i}\right) \cdot P_{b}^{i}, h>0, h^{\prime}<0, \quad i=1,2
$$

In working with equation (4), we assume that we generally operate on the concave region of the product transformation surface, which simply means that the curvature of the $g($. function in equation (1), which reflects opportunity costs for bundles vis-à-vis wheat, dominates reduced-form scale effects as embodied in the $b$ function over the range of relevant equilibria. When this is not the case we will be in unstable equilibria, with stability ultimately either involving equilibria like those we have just assumed, or else corner solutions. Under constant returns, the $b$ function would simply be a linear operator.

\footnotetext{
${ }^{6}$ Both superscripts and subscripts are used to denote countries. In general, superscripts denote values related to where an intermediate or final good originates, in terms of either quantities or prices. Subscripts denote the use of goods in production or consumption.

${ }^{7}$ A full derivation of this representation of monopolistic competition for traded intermediates can be found in Francois and Roland-Holst (1997).
} 
We are concerned with the impact of PTAs on trading costs as manifested as reduced-form trading costs. As such, we introduce them here as a markup on the cost of intermediates for final goods producers.

$$
P_{m,(i, j)}^{k}=P_{m}^{k} \cdot T_{m,(i, j)}^{k} T \geq 1
$$

In equation (5), $P_{m,(i, j)}^{k}$ represents the trading-cost inclusive price of intermediates from region $k$ when used in region $i$ to produce a good for region $j$, given trading costs $T_{m,(i, j)}^{k}$. For final goods production in the manufacturing sector, we assume a CES-based production function, defined over value added measured directly in units of bundles, and in terms of composite regional intermediate goods. In dual form, the cost function for a regional manufactured good is then as represented in equation (6).

$$
P_{Y}^{(i, j)}=A^{i} \cdot\left(\sum_{k=1}^{3} \omega_{m, i}^{k}\left(P_{m,(i, j)}^{k}\right)^{\frac{\rho}{\rho-1}}+\omega_{i, V A}\left(P_{b}^{i}\right)^{\frac{\rho}{\rho-1}}\right)^{\frac{\rho-1}{\rho}}, i=1,2 j=1,2,3 \quad 0<\rho<1
$$

In equation (6), the $\omega$ terms are exponential CES-weights from the underlying CES production function. In the dual context shown here, they serve as inverse cost weights for mapping input prices into final good prices.

Note that with constant returns under a CES production technology involving value-added and assembly, we implicitly assume that production can be separated between production for home, partner, and ROW markets to reflect relative input cost variations as detailed below. This means we can index cost of production of $Y$ by destination market. Again, we are also interested in potential trading costs, and so again introduce a trading cost wedge on final goods.

$$
P_{Y, j}^{(i, j)}=P_{Y}^{(i, j)} T_{Y, j}^{i}, T \geq 1, i \neq j
$$

In equation (7) $P_{(Y, i)}^{(i, j)}$ denotes the producer price of good $Y$ produced in region $i$ for consumption in region $j$ while $P_{(Y, i), j}^{(i, j)}$ denotes the consumer price of the same good given final-good trading cost $T_{Y, j}^{i}$. 
From equation (6), and the first-order conditions for cost-minimization in $Y$ production, we also can map composite intermediate input demand to relative internal prices and the total quantity produced. This is represented below in equation (8).

$$
m_{(i, j)}^{k}=\omega_{m, i}^{k}\left(\frac{P_{Y}^{(i, j)}}{P_{m,(i, j)}^{k}}\right)^{\sigma} Y^{(i, j)}, \quad \sigma=\frac{1}{1-\rho}
$$

In equation (8), $m_{(i, j)}^{k}$ denotes intermediates produced in region $k$ and used in region $i$ for final goods production destined for region $j$. We can make a similar derivation for total value-added $V A$, represented by equation (9) below.

$$
V A^{(i, j)}=\omega_{i, V A}\left(\frac{P_{Y}^{(i, j)}}{P_{b}^{i}}\right)^{\sigma} Y^{(i, j)}
$$

When we combine intermediates demand and value added we then have total demand for factor bundles in the manufacturing sector. This is shown in equation (10), where the $b$ function represents the primal mapping technology in equation (4) from factor input bundles employed in $m$ production to $m$ itself.

$$
b^{i}=h^{i}\left(\sum_{j=1}^{3} \sum_{k=1}^{3} m_{(j, k)}^{i}\right)+\sum_{j=1}^{3} V A^{(i, j)}
$$

Turning to final demand, we assume CES preferences defined over regional final manufactured goods. Since income itself can be mapped from the price of bundles, regional demand for regional varieties will be a function of the vector of goods prices within a national economy $\mathbf{P}$ and also of bundles prices. In total (and assuming thirdcountry demand for regional goods is also a function of price in the observed equilibrium), total demand for regional varieties will be a function of the degree of substitution between varieties, as measured by the substitution elasticity $\varepsilon$, and of the price vectors for final goods and bundles.

$$
Y^{i}=D(\mathbf{P}, \mathbf{T}, \boldsymbol{\varepsilon})
$$


Together, equations (1)-(11) give us 11 sets of functional relationships that determine a comparable set of unknowns: $P_{b}^{i}, P_{W}^{i}, P_{m}^{i}, P_{m, i}^{j}, b^{i}, P_{Y}^{i}, P_{Y, j}^{i}, V A^{i}, m_{j}^{i}, Y^{i}, W^{i}$.

We now turn to the differential impact of FTAs and CUs. For a starting point, we assume a customs union within the framework spelled-out above, meaning identical external tariffs and free movement of all goods internally. With this regional integrated equilibrium as the benchmark for the country pair, we then move to introduce trading costs to reflect the introduction of rules of origin, which characterizes an important difference in practice between FTAs and customs unions. Assuming that these rules are binding, then in reduced form we will see an increase in the effective cost of using intermediates from outside the CU/FTA (see equation 5), which can in turn be mapped to an effective increase in the inverse cost weights (i.e. a drop in the weights) in equation (8). How the increase is realized depends on how the rules are operationalized. They could range from a sliding scale involving tariffs on third-country inputs to tariffs on the whole product (including FTA inputs and value added). In practice these rules are constantly evolving. For our purposes here, we simply assume that third-country intermediates used for internally traded final goods effectively cost more to use once we introduce rules of origin. The implication of such a change is immediately clear from equation (12) below, which is derived from equation (8). Equation (12) defines the relative input mix of intermediates, by country of origin, as a function of relative input costs. With the consequent shift in the cost of using third-country inputs, as they imply a cost increase related to some financial penalty like loss of duty-free treatment for the final good, we will see a downward shift in the relative importance of third-country intermediates, and a shift toward FTA-originating inputs. Hence, there will be a shift toward intermediates that are internally produced, and away from third county intermediates.

$$
\frac{m_{(i, j)}^{v}}{m_{(i, j)}^{k}}=\frac{\omega_{m, v}^{i}}{\omega_{m, k}^{i}}\left(\frac{P_{m, k}^{(i, j)}}{P_{m, v}^{(i, j)}}\right)^{\sigma} \quad v \neq k
$$

Depending on the specific form of the rules or origin and related penalties, such a shift would be made to the point where the marginal value of product of imported thirdcounty inputs exceeds penalty costs. For the present exercise (and the empirics that 
follow), the important point is just the end result. There will be a shift toward FTA inputs, if all other factors are held fixed.

At the same time, CUs themselves can involve lower cross-border trading costs than FTAs. For example, the European Union, with its single market program, has led to the dismantling of border posts across Europe, and to cross-border cooperation to speed the clearing of goods. This has the effect of reducing the cost of using internal inputs. The obvious contrast is to the border crossing-points within NAFTA, where FTA inputs still have to clear border checks. This effect will work in the opposite direction from rules of origin. In our controlled analytical experiment, where we only introduce rules of origin on an otherwise clean slate, the impact will be a relative shift toward internal intermediates. However, when we move from our hypothetical world to actual data, we will also expect to see a rising border cost as we shift from a CU to an FTA. This would imply a rising cost for use of internal intermediates, so that the shift may be in the opposite direction. The net effect is an empirical question.

A second impact of this increase in the effective cost of external inputs (relative to our integrated customs union benchmark equilibrium) will be to increase the cost of producing final manufactured goods for export to the relevant CU/FTA partner. This is shown in equation (13) below for exports from Country 1 to Country 2, which follows from manipulation of equation (6).

$$
\frac{\partial P_{Y}^{(i, j)}}{d P_{m,(i, j)}^{k}}=A^{i} \cdot\left(\sum_{k=1}^{3} \omega_{m, i}^{k}\left(P_{m,(i, j)}^{k}\right)^{\frac{\rho}{\rho-1}}+\omega_{i, V A}\left(P_{b}^{i}\right)^{\frac{\rho}{\rho-1}}\right)^{\frac{-1}{\rho}} \omega_{m, i}^{k}\left(P_{m,(i, j)}^{k}\right)^{\frac{1}{\rho-1}}>0
$$

Assuming CES demand for the final manufactured good, we will then also have a version of equation (12) that involves final goods.

$$
\frac{Y^{(k, i)}}{Y^{(v, i)}}=k\left(\frac{P_{Y, i}^{(v, i)}}{P_{Y, i}^{(j, i)}}\right)^{\varepsilon}
$$


Since we translate rules of origin into increases in the cost of using non-FTA intermediates when producing goods for sale to an FTA partner, ${ }^{8}$ from equation (13) we can derive directly the elasticity of the price of supplying a final good to an FTA partner with respect to this increase in the price of non-FTA intermediate inputs.

$$
\eta_{P_{Y}^{(i, j)} P_{m,(i, j)}^{k}}=1>\frac{\omega_{m, i}^{k} P_{m,(i, j)}^{k}}{\left.\sum_{k=1}^{3} \omega_{m, i}^{k}\left(P_{m,(i, j)}^{k}\right)^{\rho}\right)^{\rho-1}+\omega_{i, V A}\left(P_{b}^{i}\right)^{\rho}-1}>0
$$

In equation (15), the term $\eta_{P_{Y}^{(i, j)} P_{m,(i, j)}^{k}}$ is the elasticity of the cost of producing good $Y$ in country $i$ for market $j$, with respect to rules-induced increases in the price of intermediates from country $k$ when used for good destined for market $j$. What happens to the demand for inputs? Starting from equation (A.8), we can derive the change in demand for non-FTA intermediates as follows.

$$
d m_{(i, j)}^{k}=-\sigma \omega_{m, i}^{k}\left(\frac{P_{Y}^{(i, j)}}{P_{m,(i, j)}^{k}}\right)^{\sigma} Y^{(i, j)} \frac{d P_{m,(i, j)}^{k}}{P_{m,(i, j)}^{k}}+\sigma \omega_{m, i}^{k}\left(\frac{P_{Y}^{(i, j)}}{P_{m,(i, j)}^{k}}\right)^{\sigma} Y^{(i, j)} \frac{\partial P_{Y}^{(i, j)}}{\partial P_{m,(i, j)}^{k}} \frac{d P_{m,(i, j)}^{k}}{P_{Y}^{(i, j)}}
$$

This in turn can be manipulated, by dividing through our definition of $m_{(i, j)}^{k}$, to yield the percent change in intermediate demand.

$$
\frac{d m_{(i, j)}^{k}}{m_{(i, j)}^{k}}=-\sigma \frac{d P_{m,(i, j)}^{k}}{P_{m,(i, j)}^{k}}+\sigma \frac{\partial P_{Y}^{(i, j)}}{\partial P_{m,(i, j)}^{k}} \frac{d P_{m,(i, j)}^{k}}{P_{Y}^{(i, j)}} \frac{P_{m,(i, j)}^{k}}{P_{m,(i, j)}^{k}}
$$

Finally, dividing through by relative price changes, and making a substitution from equation (15), we arrive at an elasticity representation of the impact of rules-induced non-FTA intermediate goods price increases on the use of intermediates for FTA partner-destined final goods.

\footnotetext{
${ }^{8}$ Obviously, such rules do not apply directly to the choice of inputs used to serve third (non-FTA markets). Neither are they immediately relevant for production for the home market. Where they bite is in the production of goods for export to the FTA partner.
} 


$$
\eta_{m_{(i, j)}^{k} P_{m,(i, j)}^{k}}=-\sigma\left(1-\eta_{P_{Y}^{(i, j)} P_{m,(i, j)}^{k}}\right)<0
$$

In the context of a given set of world equilibrium prices, deviations in internal prices from world benchmark prices are directly defined by deviations in the effective trading cost imposed by rules of origin.

$$
\hat{P}_{m,(i, j)}^{k}=\hat{T}_{m,(i, j)}^{k}
$$

This in turn means that equation (18), following a substitution from equation (19), yields the impact of such trading costs on intermediate input demand.

$$
\eta_{m_{(i, j)}^{k} T_{m,(i, j)}^{k}}=-\sigma\left(1-\eta_{P_{Y}^{(i, j)} T_{m,(i, j)}^{k}}\right)<0
$$

Note that in equation (20), we have also taken advantage of equation (19), which implies that $\eta_{P_{Y}^{(i, j)} T_{m,(i, j)}^{k}}=\eta_{P_{Y}^{(i, j)} P_{m, i}^{k}(i, j)}$ and where the second term is defined in equation (A.15). The shift in relative intermediate import demand in the production process for each final product line follows directly from the definition of substitution elasticities as used in the cost and input demand equations above.

$$
\begin{aligned}
& \hat{m}_{(i, j)}^{v}-m_{(i, j)}^{k}=\sigma\left(\hat{P}_{m, k}^{(i, j)}-\hat{P}_{m, v}^{(i, j)}\right) \quad v \neq k \\
& \eta_{\frac{m_{(i, j)}^{v}}{m_{(i, j)}^{k}}, \frac{P_{(i, j)}^{k}}{P_{(i, j)}^{v}}}=\sigma>0
\end{aligned}
$$

Consider next the impact on relative final product demands, and hence on relative trade shares for final products. Again, assuming CES final demands, the shift in relative final goods demand follows directly from the definition of the substitution elasticity, this time from equation (14).

$$
\begin{gathered}
\left(\hat{Y}^{(k, i)}-\hat{Y}^{(v, i)}\right)=\varepsilon\left(\hat{P}_{Y, i}^{(v, i)}-\hat{P}_{Y, i}^{(j, i)}\right) \\
\eta_{\frac{Y^{(3,1)}}{Y^{(2,1)}}, T_{m,(2,1)}^{3}}=\varepsilon \eta_{P_{Y}^{(2,1)} T_{m,(2,1)}^{3}}>0
\end{gathered}
$$


In equation (22), $\eta_{\frac{Y^{(i, 1)}}{Y^{(2,1)}}, T_{m,(2,1)}^{3}}$ represents the elasticity of relative final product demand for goods consumed in region 1, with respect to a rules-induced change in the cost of using intermediates from country 2 (an FTA partner) to produce goods for consumption in region 1. Again, we have taken advantage of the relationship of rules-induced costs to prices, given that we are working in the context of a given set of world equilibrium prices. Consider next the impact on actual rather than relative trade flows. This follows from final product demand elasticities, and the impact of rules-based trading costs for intermediates on the price of final goods (from equation 15).

$$
\eta_{Y^{(2,1)}, T_{m(2,1)}^{3}}=\eta_{Y^{(2,1)}, P_{Y, 1}^{(2,1)}} \eta_{P_{Y}^{(2,1)}, T_{m(2,1)}^{3}}<0
$$

Taken together, equations (20) and (23) say that we expect a drop in intra-FTA trade in final goods under increasingly restrictive rules of origin.

Next, we turn to the cross-price effects of rules-induced trade costs on intra-FTA demand for intermediate inputs. We again start from equations (5) and (8).

Differentiating equation (8) for cross-price effects yields equation (24).

$$
\begin{aligned}
& \partial m_{(i, j)}^{k}=\sigma \omega_{m, i}^{k}\left(\frac{P_{Y}^{(i, j)}}{P_{m,(i, j)}^{k}}\right)^{\sigma} Y^{(i, j)} P_{Y}^{(i, j)^{-1}} \frac{\partial P_{Y}^{(i, j)}}{\partial P_{m,(i, j)}^{v}} d P_{m,(i, j)}^{v} \\
& +\omega_{m, i}^{k}\left(\frac{P_{Y}^{(i, j)}}{P_{m,(i, j)}^{k}}\right)^{\sigma} \frac{\partial Y^{(i, j)}}{\partial P_{m,(i, j)}^{v}} d P_{m,(i, j)}^{v} \quad v \neq k
\end{aligned}
$$

Some further manipulation yields equation (25), which can then be summarized in elasticity form as in equation (26). 


$$
\begin{aligned}
& \frac{\partial m_{(i, j)}^{k} \frac{P_{m,(i, j)}^{v}}{m_{(i, j)}^{k}}}{d P_{m,(i, j)}^{v}}=\sigma \omega_{m, i}^{k} P_{Y}^{(i, j)^{-1}} \frac{\partial P_{Y}^{(i, j)}}{\partial P_{m,(i, j)}^{v}} P_{m,(i, j)}^{v} \\
& +\left(Y^{(i, j)}\right)^{-1} \frac{\partial Y^{(i, j)}}{\partial P_{m,(i, j)}^{v}} P_{m,(i, j)}^{v} \\
& \eta_{m_{(i, j)}^{k}, P_{m,(i, j)}^{v}} \quad=\sigma \omega_{m, i}^{k} \eta_{P_{Y}^{(i, j)}, P_{m,(i, j)}^{v}} \quad+\eta_{Y^{(i, j)} P_{m,(i, j)}^{v}}
\end{aligned}
$$

In Equation (26), the term $\eta_{m_{(i, j)}^{k}, P_{m, i, j)}^{v}}$ measures the marginal shift toward region $k$ inputs as rules of origin discriminate against region $v$ inputs. The equation says that at the margin, rules-of-origin may yield more or less trade in intermediate inputs. On the one hand, they force a substitution toward FTA-origin parts and away from outside supplies of intermediates in the production of goods destined for the FTA partner. This has a positive effect on intra-FTA demand for intermediates (and hence on internal trade). On the other hand, these rules also drive up prices, which forces overall demand toward non-FTA supplies of final goods. This depresses overall demand for intermediate goods. Finally, we turn to the relative composition of intermediate and final goods in bilateral trade flows. We define the change in imported FTA intermediates used for intra-FTA exports of the final good Y relative to the change in intra-FTA imports from of the final

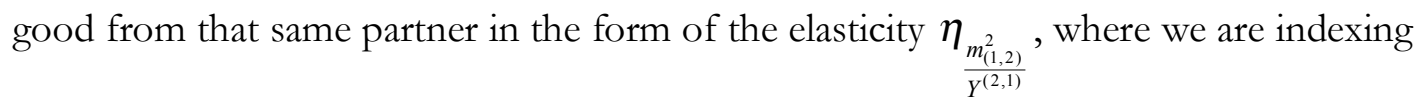
trade of goods produced in region 1 and sold in region 2. Working from equations (23) and (26), we then have the following result:

$$
\begin{aligned}
\eta_{\frac{m_{(1,2)}^{2}}{Y^{(2,1)}}} & =\eta_{m_{(1,2)}^{2}, P_{m,(1,2)}^{3}}-\eta_{Y^{(2,1)}, P_{m(2,1)}^{3}} \\
& =\sigma \omega_{m, 1}^{2} \eta_{P_{Y}^{(1,2)}, P_{m,(1,2)}^{3}}+\eta_{Y^{(1,2)} P_{m,(1,2)}^{3}}-\eta_{Y^{(2,1)}, P_{Y, 1}^{(2,1)}} \eta_{P_{Y}^{(2,1)}, P_{m(2,1)}^{3}}
\end{aligned}
$$

Starting with a customs union as a benchmark, these results imply a set of stylized shifts in the pattern of production and trade that can be expected if we observe different rules of origin across pairs of countries within a given global trading equilibrium. These can be summarized as follows. 
- Observation 1: With the introduction of binding rules of origin against thirdcountry intermediate goods, the volume of trade in finished goods will fall between FTA partners, all other things being equal. This follows from equation (23).

- Observation 2: Import demand for finished goods in the manufacturing sector will shift away from FTA partners and toward third-country suppliers as a result of imposing rules of origin for intermediate goods onto an FTA. This follows from equation (22).

a Observation 3: In contrast to final goods, demand for intermediate goods will shift away from third-country suppliers, and toward FTA-partner suppliers as a result of imposing binding rules of origin. This follows from equation (21).

- Observation 4: The volume of internal trade in intermediates may rise or fall, depending on substitution effects at given levels of production, weighed against the drop in final good production for the internal market. This follows from equation (25).

What happens to the relative composition of intra-FTA trade, in terms of intermediates and final goods? We expect a drop in intra-FTA trade in finished goods from Observation 1. The effect on intermediates is murkier. Two opposing forces drive the trade in intermediates. It may go up due to substitution or down if the impact on the cost of production is strong enough to drive down total production of final goods sufficiently. This second effect is probably second-order though, so that the intermediate goods volume should also go up. If we focus on the FTA imports of final goods by Country 1 from Country 2 and exports of intermediates from Country 1 to Country 2, this ratio will fall, since even if exports of intermediates fall, they will fall at less than any drop in total targeted production of final goods for Country 1 in the Country 2 industry (because of offsetting substitution effects). We can say the same thing for comparable FTA imports of final goods and exports of intermediates between Country 2 and Country 1. However, when we look strictly at bilateral exports of Country 1 to Country 2, or Country 2 to Country 1, we have an ambiguity following from Observations 1 and 4. We summarize these results as follows: 
- Observation 5: The expected relative allocation of total trade between Countries 1 and 2 will shift from final goods to intermediates as we introduce binding rules of origin.

- Observation 6: For Country 1, the expected relative allocation between total exports of intermediates to Country 2 and imports of final goods from Country 2 will shift to intermediates as we introduce binding rules of origin.

- Observation 7: For Country 1, the expected relative allocation between total imports of intermediates from Country 2 and imports of final goods from Country 2 will be ambiguous.

One way to read Observation 6 is that binding rules of origin will drive down the size of offshore assembly activities as measured in terms of final goods within the FTA, even as the FTA-content of those activities goes up measured in terms of the mix of intermediate goods consumption. Of course, in all the discussion of final goods here we are holding discrimination against finished vehicles constant. If FTA implementation also introduces an additional element of discrimination against third-country finished goods relative to our customs union benchmark, such direct effects will likely outweigh the indirect ones stressed here.

In all fairness, when moving from theory to empirics, these results must be approached with caution. By construction, CUs and FTAs involve a great deal more than just rules of origin. They are packages that can include harmonization and mutual recognition of standards, acceleration of customs clearance procedures, and deregulation of foreign direct investment. Such regime shifts and policy differences, which have been effectively sterilized in this section, can be quite dramatic, and may outweigh the direct effects of rules of origin in the data.

\section{Motor Vehicles and Parts}

a. The data

We next turn to a more formal empirical assessment. This involves data on the value of motor vehicles trade from UNCTAD's COMTRADE dataset for 2001, supplemented with estimates of bilateral tariff rates taken from World Bank's WITS dataset. The data 
are for trade in motor vehicles, represented by SIC (rev1) 732, which is all motor vehicles and parts, and SIC 7328 (rev 1), which is motor vehicle parts only. We have relatively complete data for bilateral trade between 27 OECD Member and associate countries: Australia, Austria, Belgium, Canada, Switzerland, the Czech Republic, Germany, Denmark, Spain, France, Great Britain, Greece, Hungary, Ireland, Italy, Japan, Korea, Mexico, the Netherlands, Norway, Poland, Portugal, Sweden, Turkey, and the United States. These countries cover a range of preferential arrangements. In addition to the NAFTA (U.S., Canada, Mexico), and the European Union, we also have FTAs within Europe through EFTA (Norway and Switzerland), the European Economic Area (EFTA and the EU, but without Switzerland), and an EU-Turkey customs union. In addition, the EU has extended FTA status to the East European economies in this period (Poland, Hungary and the Czech Republic), as has EFTA. Japan, Korea, and Australia are left out of these arrangements entirely (though Australia and New Zealand have an FTA). Critically, since roughly 1997, the EU has also negotiated a set of European accumulation rules on most though not all of its FTA partners. As a result, many countries that were in a hub-and-spoke arrangement with the EU now benefit from Europe-wide rules of origin, with the net effect being a relatively large Europe-wide FTA, with the EU15 at the center. The implementation of the arrangement, however, excluded Turkey at the time, though it did include candidate countries (the new 10 EU Members). In short, the cross-section provides a nice sample of rules of origin arrangements.

b. Regression Model and Results

We are interested in the apparent relationship between FTA vs. customs union membership, on the one hand and hence the assumed or explicit application or nonapplication of rules of origin, and on the other hand the pattern of trade and the relative importance of intermediate and final product trade as outlined in Section 2 above. Our focus will be on the relative importance of individual partners for trade in motor vehicles and parts. By implication, and as summarized above in Section 2, a shift toward traded intermediates also implies a shift in production toward intra-FTA intermediates.

We define an index for intermediates trade, $\zeta 1$. This measures the relative importance of a trading partner in total imports of intermediates. 


$$
\begin{aligned}
\zeta 1^{i, j} & =\log \left(\frac{z 1^{i, j}}{1-z 1^{i, j}}\right) \\
z 1^{i, j} & =\frac{V_{S I C 7328}^{i, j}}{\sum_{k} V_{S I C 7328}^{i, k}}
\end{aligned}
$$

From Observation 3 above, we expect $\zeta 1$ to rise for an FTA imposing binding rules of origin, relative to an otherwise comparable customs union.

We are also interested in the composition of final vs. intermediates goods trade. In theory, restrictions on the use of intermediates should cause the relative importance of parts to rise within an FTA. This assumes we hold final goods protection constant. However, in practice the forces that drive protection of intermediates will also drive rules-based protection of final goods production. Hence, the net effect really is theoretically ambiguous. To measure these relative effects, we introduce a second index, which is the ratio of intermediate imports to final good imports.

$$
\zeta 2^{i, j}=\log \left(\frac{V_{S I C 7328}^{i, j}}{V_{S I C 732}^{i, j}}\right)
$$

From observation 7 , this effect will be ambiguous.

An econometric model is estimated for both indexes above. Since the $z^{1}$ index is a share, a logistic transformation is first performed. Two samples are covered in the estimates in Tables 1 and 2. One is a sub-sample, restricted to European countries with free trade either as part of the European Union, or as part of various European FTAs, all subject to pan-European accumulation rules. The second set of regressions involves a full sample of OECD countries as both importers and/or exporters. Right hand side variables are explained in the tables.

Starting with the share of total intermediates trade (Table 1) several results stand out. First, there is a border effect, both in Europe, and globally. This means that national shares of intermediates trade increase when countries share a border. This implies that multiple border crossings add economic distance. However, a second effect relates to borders within a customs union. Borders do not matter so much (i.e. the border effect more or less goes away) when we focus on intermediates trade within the European Union (our customs union in the sample) though they matter otherwise, both within Europe, and globally. Another point to note is that, apart from borders, there is 
no discernable difference between the EU and EEA pattern of trade within Europe. The rules governing pan-European accumulation do seem to work, in that they confer most of the benefits that follow from trade between EU Members. Again, this is apart from the border effects. Finally, both European and NAFTA preferential trade arrangements lead to discrimination against third countries. However, the NAFTA regime is much stronger, leading to a greater shift away from third country suppliers, even after we control for differences in tariffs.

We next turn to relative trade in intermediates and final goods. Here, the results suggest that there is discrimination in final automobiles, in addition to automobile parts, against third countries, while there is at the same time no noticeable difference again within a European context. As a result, the pattern of imports from third countries is more focused on parts than on final goods for both the European and North American markets. Tariffs themselves have the expected effect, driving a shift from two-way trade in parts and toward final goods trade. Yet, controlling for tariffs, the regimes in both Europe and North America drive a similar shift in total trade (finished vehicles and parts) away from finished vehicles and into parts. The coefficients on these effects are virtually identical for both Europe and North America.

\section{Summary}

This paper is concerned with preferential trade agreements with two-way trade in intermediates, emphasizing patterns of production and trade and the relative importance of trade in intermediates with third countries. This includes a discussion of the analytical implications of rules of origin in a world with Ethier-type two-way trade in differentiated intermediate goods. The analytical approach introduces an innovation involving construction of a theoretical framework around an actual trade equilibrium. Individual pairs of countries are examined within the equilibrium defined by this set of world prices, to isolate and identify the impact that rules of original will have on preferential free trade. Results point to systematic differences in the composition of trade between final and intermediate goods, and the relative importance of preferential trade partners as suppliers of final and intermediate goods.

The analytical discussion is followed by an empirical examination of the implied impact of PTAs, rules of origin (a critical divide between FTAs and customs unions), and border effects on the pattern of intra-OECD trade in motor vehicle parts. There is evidence that such rules do cause a systematic shift in the composition of trade in 
intermediate goods away from third-countries, after we control for actual tariff preferences. There appears to be a particularly strong shift toward inputs sourced from FTA partners with the NAFTA, relative to expected trade under a customs union or European pan-accumulation rules. At the same time, there is no apparent evidence that North American rules have a different that European ones on the pattern of final goods trade relative to intermediates. 


\section{References}

Baldwin, R.E. (2001), "Regulatory Protectionism, Developing Nations and a Two-Tier World Trading System," Brookings Trade Forum, volume 3, 237-280, The Brookings Institution, 2001.

Bhagwati, J. and A. Panagariya (1996), "The Theory of Preferential Trade Agreements: Historical Evolution and Current Trends," American Economic Review, Vol. 86 (2) pp. $82-8$

Duttagupta, R. and A. Panagariya (2001), "Free Trade Areas and Rules of Origin: Economics and Politics," University of Maryland mimeo.

Ethier, W. (1979), "Internationally Decreasing Costs and World Trade," Journal of International Economics, 9: 1-24.

Ethier, W. (1982), "National and International Returns to Scale in the Modern Theory of International Trade," American Economic Review, 72 (June), 950-959.

Falvey, R. and G. Reed (1998), "Economic Effects of Rules of Origin," Weltwirtschaftliches Archiv 134:2.

Francois, J. and D. Nelson (2002), “A Geometry of Specialization,” Economic Journal, vol. 112 , issue 481, pages 649-67.

Francois, J.F., and D.W. Roland-Holst (1997), "Scale Economies and Imperfect Competition," in J.F. Francois and K.A. Reinert, eds., Applied Methods for Trade Policy Analysis: A Handbook, Cambridge University Press, 1997.

Harrison, G.W, T.F. Rutherford, and D.Tarr (1997), "Economic Implications for Turkey of a Customs Union with the European Union," European Economic Review, 41(3-5): 861870, April.

Ju, J. and K. Krishna (1998), "Firm Behavior and Market Access in a Free Trade Area with Rules of Origin,” NBER Working Paper No 6857.

Krishna, K. and A.O. Krueger (1995), "Implementing Free Trade Areas: Rules of Origin and Hidden Protection," in New Directions in Trade Theory, A. Deardorff, J. Levinsohn and R. Stern, eds., University of Michigan Press. 
Lopez-de-Silanes, F., J.R. Markusen, and T.F. Rutherford, "Complementarity and increasing returns in intermediate inputs", Journal of Development Economics 45, 133-151, 1994.

Markusen, J.R., T.F. Rutherford and L. Hunter, "Trade liberalization in a multinationaldominated industry", Journal of International Economics 38, 95-118, 1995.

Panagariya, A. (2000), "Preferential Trade Liberalization: The Traditional Theory and New Developments," Journal of Economic Literature XXXVIII, 287-331. 
Table 1: OLS estimates with robust standard errors

$\zeta 1$ Partner share of total imports of parts

\begin{tabular}{|c|c|c|c|}
\hline Variable & Description & $\begin{array}{l}\text { Sample 1: } \\
\text { European } \\
\text { customs union } \\
\text { or European } \\
\text { accumulation } \\
\text { rules }\end{array}$ & $\begin{array}{l}\text { Sample 2: } \\
\text { All countries }\end{array}$ \\
\hline BORDER & $\begin{array}{l}\text { 1: country pair shares a } \\
\text { border } \\
0 \text { : otherwise }\end{array}$ & $\begin{array}{l}0.628 \\
(2.06, .040)\end{array}$ & $\begin{array}{l}0.716 \\
(2.32, .021)\end{array}$ \\
\hline CU_BORDER & $\begin{array}{l}\text { 1: country shares a border } \\
\text { and both are EU Members } \\
0: \text { otherwise }\end{array}$ & $\begin{array}{l}-0.712 \\
-(1.59, .060)\end{array}$ & $\begin{array}{l}-0.661 \\
-(1.75, .081)\end{array}$ \\
\hline LNDISTW & The natural log of distance & $\begin{array}{l}-1.435 \\
-(6.64, .000)\end{array}$ & $\begin{array}{l}-1.002 \\
-(5.98, .051)\end{array}$ \\
\hline $\ln T$ & $\log (1+t)$ & $\mathrm{N} / \mathrm{A}$ & $\begin{array}{l}-2.141 \\
-(1.11, .267)\end{array}$ \\
\hline not-EU & $\begin{array}{l}\text { 1: importer is and EU } \\
\text { Member, but partner is not } \\
0: \text { otherwise }\end{array}$ & $\begin{array}{l}-0.334 \\
-(0.69, .493)\end{array}$ & $\mathrm{N} / \mathrm{A}$ \\
\hline not_NAFTA & $\begin{array}{l}\text { 1: importer is a NAFTA } \\
\text { member, but partner is not }\end{array}$ & $\mathrm{N} / \mathrm{A}$ & $\begin{array}{l}-3.215 \\
-(6.68, .000)\end{array}$ \\
\hline \multirow[t]{2}{*}{ not_EEA } & $\begin{array}{l}\text { 1: importer is an EEA } \\
\text { member (EU, EFTA, } \\
\text { CEFTA) and partner is not } \\
0: \text { otherwise }\end{array}$ & $\mathrm{N} / \mathrm{A}$ & $\begin{array}{l}-1.084 \\
-(2.36, .019)\end{array}$ \\
\hline & & $\begin{array}{l}\text { R-sq: } .8800 \\
\text { obs: } 297 \\
\text { d.f.: } 257\end{array}$ & $\begin{array}{l}\text { R-sq: } .8310 \\
\text { obs: } 621 \\
\text { df: } 563\end{array}$ \\
\hline
\end{tabular}

Estimated are based on OLS regressions with robust standard errors. Since left-hand side variables are measured as shares, dependant variables in the regressions are logistic transformations of the original share terms. t-ratios are given in parentheses "( )" with significance levels in italics. For the first regression, sample is restricted to EU Members and countries that have otherwise implemented pan-European accumulation rules. 
Table 2: OLS estimates with robust standard errors

$\zeta 2$ Relative importance of intermediates versus final goods in bilateral imports

\begin{tabular}{|c|c|c|c|}
\hline Variable & Description & $\begin{array}{l}\text { Sample 1: } \\
\text { European } \\
\text { customs union } \\
\text { or European } \\
\text { accumulation } \\
\text { rules }\end{array}$ & $\begin{array}{l}\text { Sample } 2: \\
\text { All countries }\end{array}$ \\
\hline BORDER & $\begin{array}{l}\text { 1: country pair shares a } \\
\text { border } \\
0 \text { : otherwise }\end{array}$ & $\begin{array}{l}0.239 \\
(0.34, .073)\end{array}$ & $\begin{array}{l}0.328 \\
(0.65, .514)\end{array}$ \\
\hline CU_BORDER & $\begin{array}{l}\text { 1: country shares a border } \\
\text { and both are EU Members } \\
0: \text { otherwise }\end{array}$ & $\begin{array}{l}-0.457 \\
-(0.60, .549)\end{array}$ & $\begin{array}{l}-0.045 \\
-(0.07, .947)\end{array}$ \\
\hline LNDISTW & The natural log of distance & $\begin{array}{l}-0.757 \\
-(0.12, .901)\end{array}$ & $\begin{array}{l}-0.043 \\
-(0.09, .928)\end{array}$ \\
\hline $\ln T$ & $\log (1+t)$ & $\mathrm{N} / \mathrm{A}$ & $\begin{array}{l}-15.211 \\
-(2.60, .010)\end{array}$ \\
\hline not-EU & $\begin{array}{l}\text { 1: importer is and EU } \\
\text { Member, but partner is not } \\
0: \text { otherwise }\end{array}$ & $\begin{array}{l}0.022 \\
-(0.02, .984)\end{array}$ & $\mathrm{N} / \mathrm{A}$ \\
\hline not_NAFTA & $\begin{array}{l}\text { 1: importer is a NAFTA } \\
\text { member, but partner is not }\end{array}$ & $\mathrm{N} / \mathrm{A}$ & $\begin{array}{l}2.397 \\
(1.92, .056)\end{array}$ \\
\hline \multirow[t]{2}{*}{ not_EEA } & $\begin{array}{l}\text { 1: importer is an EEA } \\
\text { member (EU, EFTA, } \\
\text { CEFTA) and partner is not } \\
\text { 0: otherwise }\end{array}$ & $\mathrm{N} / \mathrm{A}$ & $\begin{array}{l}2.606 \\
(1.98, .048)\end{array}$ \\
\hline & & $\begin{array}{l}\text { R-sq: } .8800 \\
\text { obs: } 297 \\
\text { d.f.: } 257\end{array}$ & $\begin{array}{l}\text { R-sq: } .4089 \\
\text { obs: } 585 \\
\text { df: } 56\end{array}$ \\
\hline
\end{tabular}

Estimated are based on OLS regressions with robust standard errors. Since left-hand side variables are measured as shares, dependant variables in the regressions are logistic transformations of the original share terms. t-ratios are given in parentheses "( )" with significance levels in italics. For the first regression, sample is restricted to EU Members and countries that have otherwise implemented pan-European accumulation rules 